\title{
Systematics and paleoecology of the foraminifer Neoeponides duwi (Nakkady) from the Paleocene of Egypt
}

\author{
Robert P. Speijer \\ Department of Geosciences, Bremen University, P.O. Box 330440, 28334 Bremen, Germany \\ email: speijer@uni-bremen.de
}

\begin{abstract}
The holotype of Neoeponides duwi (Nakkady 1950), originally described as a variety of Discorbis pseudoscopos Nakkady, is re-described and re-figured. This species appears to have no phylogenetic relationship with $D$. pseudoscopos. Neoeponides duwi is recorded in Paleocene shelf sediments in the Middle East and, assigned to Eponides pseudoelevatus, in West Africa. In Egypt, $N$. duwi typically occurs in inner to middle shelf deposits, but it has also been found dominant (up to $60 \%$ of the benthic assemblage) in transgressive deposits in deeper parts of the basin. Its distribution pattern, the association with highly variable and occasionally extremely high plankton/benthos ratios (>99.5\% plankton) and with TOC-enriched laminated dark sediments, suggests an opportunistic response to limited and/or variable oxygenation at the seafloor.
\end{abstract}

\section{INTRODUCTION}

A first account of the taxonomy and stratigraphic distribution of Maastrichtian to early Eocene foraminifera in Egypt was provided by Nakkady (1950). From five outcrops close to the Red Sea and the Gulf of Suez, Nakkady recorded a total of 168 species and varieties of which 19 species and 17 varieties were considered new. Most of the newly described species and varieties, largely consisting of benthic taxa, were subsequently observed in numerous other localities in Egypt and elsewhere in North Africa and the Middle East (e.g. Reiss 1952; LeRoy 1953; Said and Kenawy 1956; Aubert and Berggren 1976; Salaj et al. 1976; Luger 1985; Saint-Marc and Berggren 1988; Speijer 1994; Schnack 2000). Despite the central position of the work of Nakkady (1950) in subsequent micropaleontological studies in the region, the taxonomy of many of the species he erected are poorly constrained: descriptions are generally very brief and the illustrations rather sketchy. Consequently, there is a need for clarification of the taxonomic status of his species, particularly of the common ones and those that have biostratigraphic, paleoecologic, or paleogeographic value.

In an earlier paper, the taxonomic status and biostratigraphic value of Globanomalina luxorensis (Nakkady 1950) in Tethyan deposits was extensively discussed with respect to recognizing the interval of the Paleocene-Eocene thermal maximum and related biotic changes (Speijer and Samir 1997). In this paper, another of Nakkady's species with an interesting distribution pattern is discussed. This species was originally defined as Discorbis pseudoscopos var. duwi Nakkady 1950, which holotype was derived from the lowermost Paleocene shales of Gebel Duwi, Red Sea coast, Egypt (text-fig. 1) (Nakkady 1950). We refer to this species as Neoeponides duwi and confirm the observation of Nakkady (1950) that this taxon is abundant in a few levels within the basal Paleocene shales in the Gebel Duwi section. Recently, Neoeponides duwi was also recognized as a common to abundant species in Paleocene shallow shelf deposits in southern central Egypt (Anan and Sharabi 1988; Hewaidy 1994; Schnack 2000). In the deeper shelf deposits in the Nile Valley, this species is usually absent, except for an interval comprising the Danian-Selandian transition, where it dominates (up to $60 \%$ ) the benthic foraminiferal assemblages (Speijer and Schmitz 1998; Speijer in press). Speijer and Schmitz (1998) interpreted this dominance as reflecting lowstand deposition after a $\sim 150 \mathrm{~m}$ relative sea-level fall. Additional data on the distribution of $N$. duwi, which is occasionally associated with extremely high $\mathrm{P} / \mathrm{B}$ ratios and TOC-enriched sediments, suggested that the brief dominance of $N$. duwi in the Nile Valley rather represents a transgressive phase after a $50-100 \mathrm{~m}$ relative sea-level fall (Speijer in press). The unusual dominance of $N$. duwi associated with the Danian-Selandian transition and the possible relationship between its distribution and sea-level changes is the rationale for the taxonomic and paleoecologic evaluation presented here. Holo- and topotypes of this species, deposited in the Natural History Museum, London, were studied in the summer of 1999. Additional material from central and southern Egypt (documented by Schnack 2000) and from eastern Egypt (Gebel Aweina, Gebel Duwi, Gebel Nezzi, Gebel Qreiya; Speijer in press) was investigated for comparison. Biostratigraphic denotations follow the concepts of Berggren et al. (1995).

\section{SYSTEMATIC PALEONTOLOGY}

Class GRANULORETICULOSEA De Saedeleer 1934

Order FORAMINIFERIDA Eichwald 1938

Suborder ROTALIINA Lankester 1885

Superfamily DISCORBACEA Ehrenberg 1838

Family ROSALINIDAE Reiss 1963

Subfamily ROSALININAE Reiss 1963

Genus Neoeponides Reiss 1960

The position of Neoeponides in this systematic classification is uncertain. Hottinger et al. (1990) pointed out that Neoeponides lacks the typical Rosalinid features of a large folium and sutural notch. Similarly, these authors noted that this genus also lacks the typical umbilical features of the Eponidae and the Discorbidae and suggested that Neoeponides should probably placed within a new family, a view corroborated also by Hauser and Keller-Grünig (1993). 
Neoeponides duwi (Nakkady)

Plate 1, figures 2a-c, 3, 4, 5a-b, 6, 7

Discorbis pseudoscopos var. duwi NAKKADY 1950, p. 689, pl. 90, figs. 5-7.

Eponides pseudoelevatus GRAHAM, DE KLASZ and RÉRAT 1965, p. 76, pl. 1, figs. 14a-c. (Holotype from the Paleocene of Gabon).

Eponides pseudoelevatus Graham, De Klasz and Rérat. - PETTERS 1982, p. 74, pl. 7, figs. 7-8.

Discorbis pseudoscopos duwi Nakkady. - ANAN and SHARABI 1988, pl. 2, fig. 15.

Discorbis duwi Nakkady. - HEWAIDY 1994, fig. 13, nos. 7, 9 (not no. 8 , which is a Lenticulina) (without description).

NOT Discorbis pseudoscopos duwi Nakkady. - ANAN 1998, p. 373, fig. 3, no. 11. (it concerns a specimen of a species referred to as Gavelinella guineana Petters and Adegoke [cf. Petters 1982; Speijer et al. 1996])

Discorbis duwiensis Nakkady. - SCHNACK 2000, p. 49 of appendix, pl. 7, figs. 15, 16.

Description: A large trochospiral species with prominent septal elevations on the spiral side. Radial wall structure with large pores on both sides. Umbilical side convex with a deep umbilicus surrounded by thickened nodes of poreless clear shell material on the inner side of the radial, slightly curved septal sutures. Towards the peripheral margins the umbilical sutures become flush with the surface. Spiral side convex to flattened with about two to two-and-a-half whorls visible, about 8-9 chambers in the last whorl. Chambers slightly to strongly overlapping, with septal sutures arched and slightly to strongly oblique. These sutures as well as the spiral structure show ridge-like elevations, in the central part fusing together. The angular peripheral margin is slightly to strongly keeled. The aperture is a low arched extra-umbilical to umbilical opening, bordered by a lip. In the umbilical area the aperture is covered by a thickened but short extension of the last chamber.

Remarks: Neoeponides duwi was originally described as a variety of Discorbis pseudoscopos Nakkady (holotype: Plate 1, figs. 1a-c). Anan (1998) considered D. pseudoscopos as the precursor species of $N$. duwi. However, D. pseudoscopos, a species usually recorded as Anomalinoides umboniferus (Reuss), or Anomalina umbonifera is smooth, strongly flattened and has different umbilical features and thus cannot be considered as a close relative of $N$. duwi. The species $N$. duwi fits well within the generic concept of Neoeponides as defined by Reiss (1960) and discussed by Hottinger et al. (1990) and Hauser and Keller-Grünig (1993). Loeblich and Tappan (1987) provide a different view on the generic characters of Neoeponides and its systematic position (Hottinger et al. 1990; Hauser and KellerGrünig 1993). Typical aspects of Neoeponides differentiating also the present species from Eponides are the large pores, the absence of an apertural bipartitor and the presence of a true umbilicus (Hauser and Keller-Grünig 1993). Neoeponides duwi differs from Neoeponides elevatus (Plummer) in its usually less convex spiral side, higher chambers, more numerous chambers per whorl, the presence of a keel, and its more raised spiral sutures. In a previous paper, this species was referred to as Discorbis duwi (Speijer and Schmitz 1998). Rotalia(?) aegyptiaca Leroy 1953 from Maastrichtian deposits in central Egypt may be a precursor of $N$. duwi. It differs in its more flattened test, weakly raised spiral sutures and the absence of thickened nodes around the umbilicus.

Biogeography: This species has previously been observed in the Middle East and in western Africa. In the Middle East it was recorded in southern and central Egypt (Hewaidy 1994; Schnack 2000), in eastern Egypt (Gebel, Aweina, Gebel Duwi,

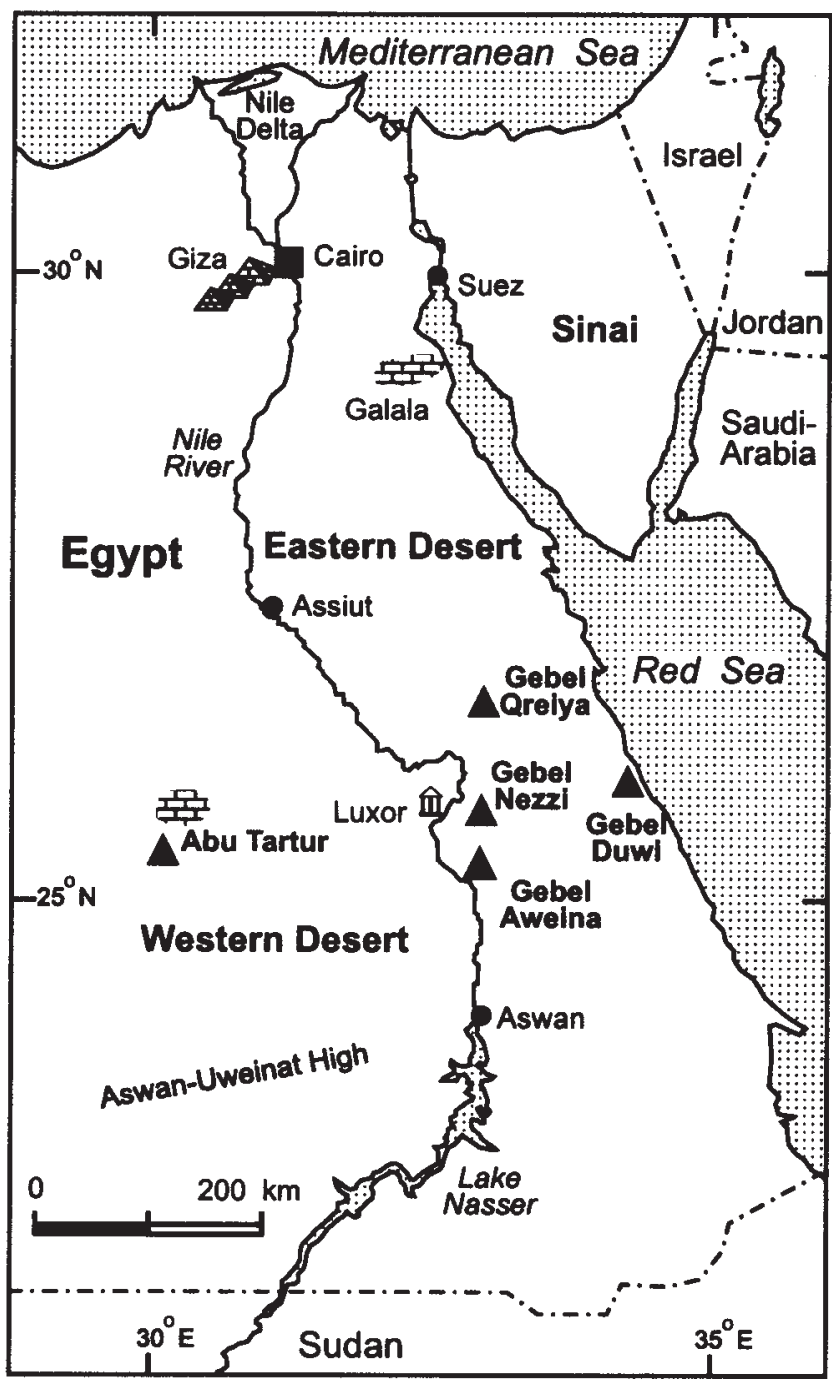

TEXT-FIGURE 1

Studied localities (triangles) in Egypt where Neoeponides duwi is observed.

Gebel Nezzi, Gebel Qreiya; Nakkady 1950 and this study), in western Jordan (Futyan 1976 as Valvulineria duwi). In western Africa it has been recorded as Eponides pseudoelevatus in Paleocene deposits of the Niger delta (Petters 1982) and in Gabon, Cameroon, and Nigeria (Graham et al. 1965). Probably the subspecies Eponides pseudoelevatus lysi (Graham, De Klasz and Rérat 1965) also falls within the range of variation of $N$. duwi. Neoeponides duwi has not yet been observed in the part of north Africa between these regions.

Stratigraphic distribution: Neoeponides duwi appears to have been an exclusively Paleocene species. In Egypt, $N$. duwi ranges from the Danian (Zone P1) to the Selandian (Zone P4). In eastern Egypt, it was observed in Zones P1b to P3a (Schnack 2000; Speijer, in press). In southern Egypt, it appears to range slightly higher, into Zone P4 (Anan and Sharabi 1988; Hewaidy 1994), although figure 3, No. 11 in Anan (1998) suggests that a superficially similar species, referred to as Gavelinella? guineana by Speijer et al. (1996) is included within the taxonomic concept and thus may have stretched the stratigraphic range. In western 
Jordan, Futyan (1976) indicated the presence of $N$. duwi in lower to upper Paleocene deposits. Current studies on four Paleocene sections in western Jordan confirmed the occasional presence of $N$. duwi within Zones P1c to P3a (E. Guasti pers. comm., 2002). In western Africa it was recorded in Paleocene rocks without further biostratigraphic differentiation (Graham et al. 1965; Petters 1982).

Paleoecology and paleobathymetry: In central and southern Egypt, this species particularly flourished within low diversity faunas ( $<15$ species) of the inner to middle shelf (Hewaidy 1994; Schnack 2000). It occurs in the platform facies of the lower Paleocene Abu Tartur plateau as well as in marls and shales of more basinal facies. Occasionally, it occurs as the most abundant species (up to 60\%) of the benthic foraminiferal assemblage, like in Danian/Selandian transition (Subzone P3a) deposits in the Nile Valley (Speijer, in press). This unusual domination, sometimes in combination with very high $\mathrm{P} / \mathrm{B}$ ratios $(>99.5 \%$ planktics $)$ and TOC-enriched laminated dark-brown marl beds with abundant fish-remains, suggests an opportunistic mode of life of a species being able to respond rapidly to environmental perturbations. This interpretation however, would seem at odds with the rather large and thickly calcified tests of $N$. duwi. Assemblages containing $N$. duwi, recorded as "Eponides pseudoelevatus" are commonly found in various basins in western Africa too (Graham et al. 1965; Petters 1982). There, this species occurs in undifferentiated neritic deposits, but the general paucity of planktic foraminifera in the Paleocene west-African basins (e.g. Petters 1982) suggests that $N$. duwi generally occupied the shallower end of the neritic realm, like in Egypt.

\section{CONCLUSIONS}

The re-study of holotype material indicates that Neoeponides duwi is not closely related to Discorbis pseudoscopos, in contrast to the suggestions by Nakkady (1950) and Anan (1998). In Egypt, the species ranges from the lower Paleocene Zone P1 into the upper Paleocene Zone P4. In the Paleocene of West Africa the species has been recorded as Eponides pseudoelevatus. In Egypt and possibly in West African basins too, Neoeponides duwi typifies inner to middle neritic deposits. In Egypt, it is particularly abundant, composing up to $60 \%$ of the benthic assemblages, in transgressive beds associated with the DanianSelandian transition.

\section{ACKNOWLEDGMENTS}

Financial support was provided through the Deutsche Forschungsgemeinschaft (Sp-612/1 and 612/2). I thank Lukas Hottinger, Tanja Kouwenhoven, Jens Lehmann, and Ellen Thomas and for constructive criticism. I'm indebted to John Whittaker for photographic support of the holotypes of Neoeponides duwi (Nakkady) and of Discorbis pseudoscopos Nakkady. The copyright of the photographs of the holotypes (Nos. P41731 and P41733) remains with the Natural History Museum, London.

\section{REFERENCES}

ANAN, H. S., 1998. Accelerated evolution in representatives of the genera Orthokarstenia and Discorbis (benthic Foraminifera) in the Maastrichtian and Paleocene of Egypt (Misr). Neues Jahrbuch für Geologie und Palaeontologie. Monatshefte, 1998(6): 365-375.

ANAN, H. S. and SHARABI, S. A., 1988. Benthonic foraminifera from the Upper Cretaceous-Lower Tertiary rocks of the northwest Kharga Oasis, Egypt. Middle East Research Center Ain Shams University, Earth Science Series, 2: 191-218.

AUBERT, J. and BERGGREN, W. A., 1976. Paleocene benthic foraminiferal biostratigraphy and paleoecology of Tunisia. Bulletin de Centre de Recherche Pau-SNPA, 10: 379-469.

BERGGREN, W. A., KENT, D. V., SWISHER, C. C., III and Aubry, M.-P., 1995. A revised Cenozoic geochronology and chronostratigraphy. In: Berggren, W.A., Kent, D.V., Aubry, M.-P., and Hardenbol, J., SEPM Special Publication, 54: Geochronology, time scales and global stratigraphic correlation. Tulsa, OK: Society for Sedimentary Geology, pp. 129-212.

FUTYAN, A. I., 1976. Late Mesozoic and early Cainozoic benthic foraminifera from Jordan. Palaeontology, 19(3): 517-537.

\section{PLATE 1}

Scale bars $100 \mu \mathrm{m}$

la-c Holotype of the species described as Discorbis pseudoscopos Nakkady (Natural History Museum, London No. P41731)

2a-c Holotype of Neoeponides duwi (Nakkady) (Natural History Museum, London No. P41733). Note the poor visibility of the umbilical features, compared to nos. 4 and 5

3 Neoeponides duwi. Specimen with poorly developed raised sutures (Gebel Duwi, sample DU95D/S 40)

4 Neoeponides duwi. Specimen showing welldeveloped raised sutures on spiral side, sutural thickenings around the umbilicus and position of aperture bordered by a distinct lip. (Gebel Duwi, sample DU95D/S 39A)

5a-b Neoeponides duwi. Specimen showing sutural thickenings around open umbilicus and close up of the interiomarginal aperture in umbilical-extraumbilical position. (Gebel Duwi, sample DU95D/S 39A)

6 Neoeponides duwi. Large specimen with distinct ridge on the spiral suture (Gebel Aweina, sample O95D/S +19-24)

7 Neoeponides duwi. Specimen with relatively flat spiral side and well-developed raised sutures (Gebel Qreiya, sample 271185/40) 

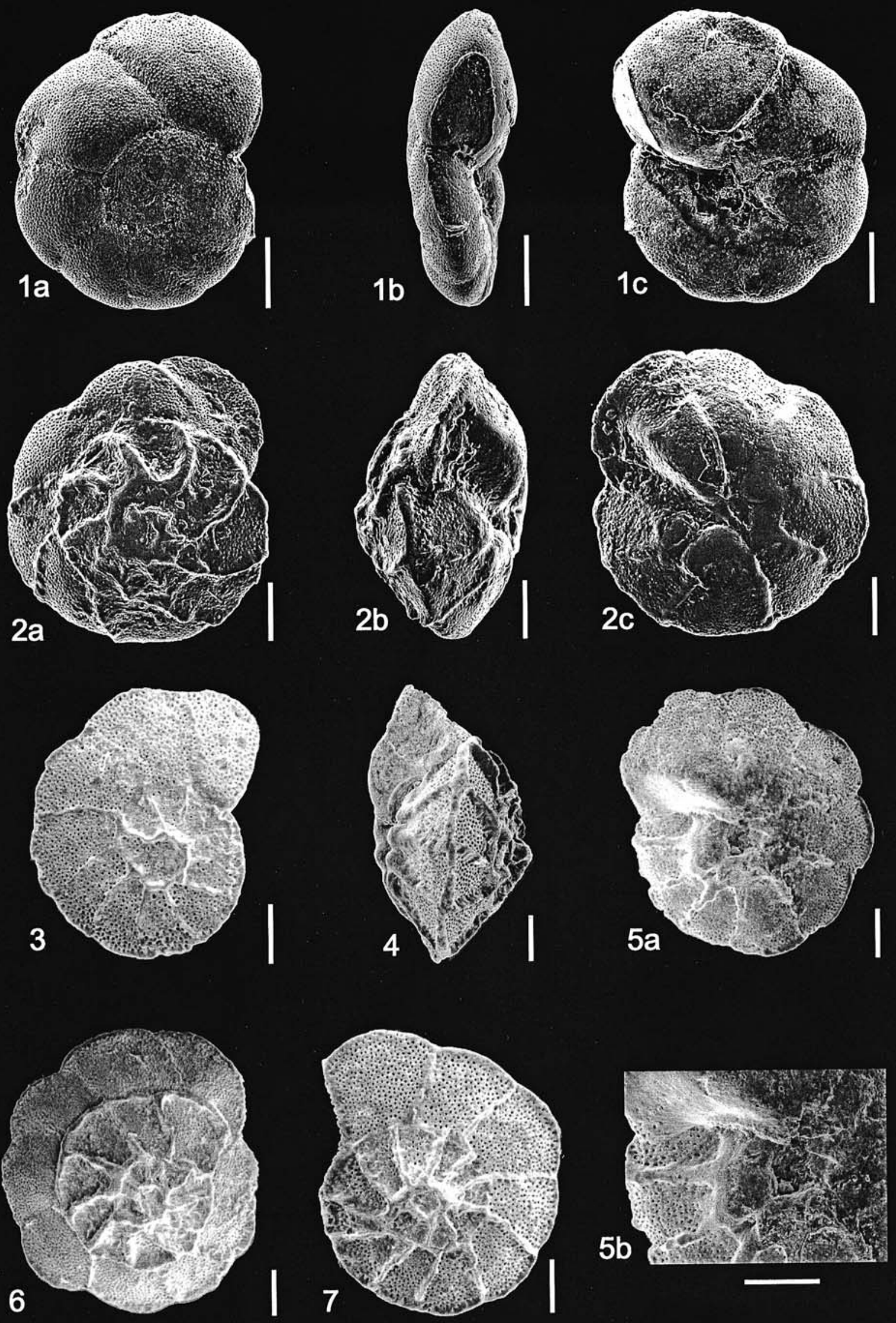
GRAHAM, J. J., De KLASZ, I. and RERAT, D., 1965. Quelques importants foraminifères du Tertiaire du Gabon (Afrique Équatoriale). Revue de Micropaléontologie, 8(2): 71-84.

HAUSER, E. H. and KELLER-GRÜNIG, A., 1993. Eponides and some related genera (Cretaceous to Recent); a taxonomic revision. Journal of Foraminiferal Research, 23(4): 238-253.

HEWAIDY, A. G. A., 1994. Biostratigraphy and paleobathymetry of the Garra-Kurkur area, southwest Aswan, Egypt. Middle East Research Center Ain Shams University, Earth Science Series, 8: 48-73.

HOTTINGER, L., REISS, Z. and HALICZ, E., 1990. Comments on Neoeponides (Foraminifera). Revue de Paléobiologie, 9(2): 335-340.

LEROY, L. W., 1953. Biostratigraphy of the Maqfi section, Egypt. Geological Society of America, Memoir, 54: $73 \mathrm{pp}$.

LOEBLICH, A. R. J. and TAPPAN, H. 1987. Foraminiferal Genera and their Classification. New York: Van Nostrand Reinhold, 970 pp.

LUGER, P., 1985. Stratigraphie der marinen Oberkreide und des Alttertiärs im südwestlichen Obernil-Becken (SW-Ägypten) unter besonderer Berücksichtigung der Mikropaläontologie, Palökologie und Paläogeographie. Berliner Geowissenschaftliche Abhandlungen, Reihe A: Geologie und Paläontologie, 63: $151 \mathrm{pp}$.

NAKKADY, S. E., 1950. A new foraminiferal fauna from the Esna shales and upper Cretaceous Chalk of Egypt. Journal of Paleontology, 24(6): 675-692.

PETTERS, S. W., 1982. Central West African Cretaceous-Tertiary benthic foraminifera and stratigraphy. Palaeontographica, Abteilung A, 179: $104 \mathrm{pp}$.

REISS, Z., 1952. On the upper Cretaceous and lower Tertiary microfaunas of Israel. Bulletin of the Research Council of Israel, 2(1): $37-50$.

1960. Structure of so-called Eponides and some other rotaliiform Foraminifera. Israel Geological Survey, Bulletin, 29: 1-19.
SAID, R. and KENAWY, A., 1956. Upper Cretaceous and lower Tertiary foraminifera from northern Sinai, Egypt. Micropaleontology, 2(2): $105-173$.

SAINT-MARC, P. and BERGGREN, W. A., 1988. A quantitative analysis of Paleocene benthic foraminiferal assemblages in central Tunisia. Journal of Foraminiferal Research, 18(2): 97-113.

SALAJ, J., POZARYSKA, K. and SZCZECHURA, J., 1976. Foraminiferida, zonation and subzonation of the Paleocene of Tunisia. Acta Palaeontologica Polonica, 21(2): 127-190.

SCHNACK, K., 2000. Biostratigraphie und fazielle Entwicklung in der Oberkreide und im Alttertiär im Bereich der Kharga Schwelle, Westliche Wüste, SW Ägypten. Doctoral Thesis, Bremen University, Bremen, 142 pp. (Berichte, Fachbereich Geowissenschaften, Universität Bremen, Nr. 151)

SPEIJER, R. P., 1994. Extinction and Recovery Patterns in Benthic Foraminiferal Paleocommunities across the Cretaceous/Paleogene and Paleocene/Eocene Boundaries. Geologica Ultraiectina, 124: 191 pp.

- in press. Danian-Selandian sea-level change and biotic excursion on the southern Tethyan margin (Egypt). In: Wing, S.L et al., Eds., Causes and Consequences of Globally Warm Climates in the Early Paleogene, GSA Special Paper, 369.

SPEIJER, R. P. and SAMIR, A. M., 1997. Globanomalina luxorensis, a Tethyan biostratigraphic marker of latest Paleocene global events. Micropaleontology, 43(1): 51-62.

SPEIJER, R. P. and SCHMITZ, B., 1998. A benthic foraminiferal record of Paleocene sea level and trophic/redox conditions at Gebel Aweina, Egypt. Palaeogeography, Palaeoclimatology, Palaeoecology, 137(1-2): 79-101.

SPEIJER, R. P., VAN DER ZWAAN, G. J. and SCHMITZ, B., 1996. The impact of Paleocene/Eocene boundary events on middle neritic benthic foraminiferal assemblages from Egypt. Marine Micropaleontology, 28(2): 99-132.

Manuscript received May 29, 2002

Manuscript accepted December 9, 2002 